\title{
Paradigmaverskuiwings en die Afrikaanse mediese vaktaal*
}

\author{
H.P. Wassermann, Voormalige Dekaan, Fakulteit Geneeskunde, \\ Universiteit van Stellenbosch, Suid-Afrika
}

\begin{abstract}
Paradigm Shifts and the Afrikaans Medical Terminology. The Paramediese Woordeboek, the first Afrikaans medical dictionary to appear in an age of international shifting paradigms in medicine, is reviewed against that background. An historical perspective on the influence of such shifts and their aims is presented, emphasising their effect on intercollegiate, communal and transactional communication. The enigma of the title concerns the intended target group, and inferred distinct technical terminology. The preface, with its claim to simplicity of definitions, and alleged problems with internationally recognised Afrikaans medical language is discussed. Constructional user-unfriendly aspects and incorrect definitions are pointed out, with a note on Afrikaans spelling. In spite of its title, it is largely a school dictionary.

A perspective on the future of medical dictionaries and paradigm shifts is presented; paradigm shifts probably have less terminological than strategic implications. The latter involves reaching and providing for the needs of disadvantaged target groups in accessing a highly specialised intercollegiate technical language.

A need for updating and revising the existing standard Afrikaans explanatory medical dictionary is emphasised; from such a revised edition user-defined explanatory wordlists could be abstracted by a panel of professionals from the intended target groups in accessing a highly specialised intercollegiate technical language. A challenging task awaits Afrikaans medical diction-
\end{abstract} aries.

Keywords: MEDICAL DICTIONARY, PARAMEDICAL, PARADIGM SHIFTS, HISTORIC PERSPECTIVE, FUTURE PERSPECTIVE, ENIGMATIC TITLE, TARGET GROUPS, CONSTRUCTION, PREFACE, PRESCRIPTIVE DEFINITIONS, SPELLING, INTERCOLLEGIATE COMMUNICATION, COMMUNAL COMMUNICATION, TRANSACTIONAL COMMUNICATION, MULTILANGUAGE DICTIONARY

Opsomming: Die Paramediese Woordeboek, die eerste Afrikaanse mediese woordeboek om in 'n era van internasionale paradigmaverskuiwings in geneeskunde te verskyn, word teen daardie agtergrond beskou. 'n Historiese perspektief op die invloed van sulke verskuiwings en hul oogmerke word gegee, met klem op interkollegiale, kommunale en transaksionele kommunikasie. Die enigma van die titel gaan oor die bedoelde teikengroep, en 'n vermoedelik afsonderlike tegniese terminologie. Die voorwoord, met sy aanspraak op eenvoudige definisies, en beweerde probleme met die internasionaal erkende Afrikaanse mediese taal word bespreek. Konstruksionele gebrui-

* Resensieartikel oor die Paramediese Woordeboek deur Lynette van Rensburg, 1996, 289 pp., ISBN 0-7986-3568-1, uitgegee deur Kagiso Uitgewers, Pretoria. 
kersonvriendelike aspekte en foutiewe definisies word aangetoon, met 'n opmerking oor die Afrikaanse spelwyse. Ten spyte van sy titel is dit hoofsaaklik 'n skoolwoordeboek.

'n Perspektief op die toekoms van mediese woordeboeke word gegee; paradigmaverskuiwings het waarskynlik minder terminologiese as strategiese implikasies. Laasgenoemde betrek die bereiking van, en voorsiening in die behoeftes van agtergeblewe teikengroepe ten einde toegang te verkry tot 'n hoogs gespesialiseerde interkollegiale tegniese taal.

Die behoefte aan bywerking van die bestaande standaard Afrikaanse verklarende woordeboek word beklemtoon; uit so 'n hersiene uitgawe kan gebruiker-gedefinieerde verklarende woordelyste ekstraheer word deur 'n paneel vakmanne uit die bedoelde teikengroep. 'n Uitdagende taak wag op Afrikaanse mediese woordeboeke.

Sleutelwoorde: MEDIESE WOORDEBOEK, PARAMEDIES, PARADIGMAVERSKUIWINGS, HISTORIESE PERSPEKTIEF, TOEKOMSPERSPEKTIEF, ENIGMATIESE TITEL, TEIKENGROEPE, KONSTRUKSIE, VOORWOORD, VOORSKRIFTELIKE DEFINISIES, SPELWYSE, KOLLEGIALE KOMMUNIKASIE, KOMMUNALE KOMMUNIKASIE, TRANSAKSIONELE KOMMUNIKASIE, VEELTALIGE WOORDEBOEK

\section{Historiese perspektief op mediese woordeboeke en paradigmaver- skuiwings}

Die Paramediese Woordeboek (PW), die eerste Afrikaanse mediese woordeboek om tydens die huidige wêreldwye paradigmaverskuiwings in geneeskunde te verskyn, moet teen hierdie agtergrond gesien en beoordeel word.

Mediese terminologie ontwikkel uit bewoordbare begrippe omtrent siektes en ongesteldhede (bv. koue vat, maansiek, duiwelbesete) — 'n voortgaande proses binne die omgangstaal. Die wetenskaplike benadering dateer vanaf Hippokrates (circa 480 v.C.), die Griekse "vader" daarvan. In antieke Rome het Griekse geneeshere, soos Galenus (130-200 n.C.) by uitstek, geneeskunde beoefen, in Latyn baie en oor alle mediese sake geskryf, en óók die eerste woordelys vir mediese studente saamgestel (MacNalty 19653: v). Sy deurlopende invloed op die geneeskunde was nog merkbaar tot die laat- agtiende eeu. Vir Marcus Aurelius was hy "die eerste onder dokters en die voorste onder filosowe", vir die Middeleeue was hy "die mediese pous", en Renaissanceanatome en -fisioloë het hom as "mentor" erken (Magner 1992: 86 e.v.). Die Grieks-Latynse oorsprong van mediese vakterme in alle wetenskapstale verklaar waarom mediese woordeboeke hul besonderlik tot vertaling in enige ander wetenskapstaal leen. ${ }^{1}$ Van Suid-Afrika se amptelike tale is slegs Engels en die inheemse Afrikaans nog wetenskapstale.

Gesondheidsdienste ontwikkel in die twintigste eeu deur drie fases: Vóór die tegnologiese ontploffing ná die Tweede Wêreldoorlog is optimale mannekragvoorsiening met klem op voorgraadse mediese onderrig nagestreef, vanaf die vyftigerjare volg spesialisasie en navorsing om diensgehalte te ontwikkel en uit te bou, en sedert die tagtigerjare verskuif die klem na gelykberegtiging op beskikbare dienste deur dit op bekostigbare wyse toeganklik vir almal te pro- 
beer maak. Elke fase het terminologiese implikasies: Die eerste moes die wetenskaplike benadering tot siekte en gesondheid verstaanbaar aan pasiënte en belangstellendes oordra, die tweede moes nuwe teoretiese begrippe en tegniese terme en medisyne- en apparatuurname skep, en in die laaste fase moet medies-ekonomiese en medies-sosiologiese begrippe onder meer bewoord word. Die wêreldwye paradigmaverskuiwing neem sedert die Alma Ata-konferensie primêre gesondheidsorg as visie en missie (World Health Organisation and UNICEF 1978).

Tydens paradigmaverskuiwings herleef en groei die gewildheid van alternatiewe geneeskunde. Alternatief beskryf in dié konteks "ander gesondheidspraktisyns as die ortodokse", en sluit onder altesaam 27 ander in die VSA homeopate, herbaliste, chiropraktisyns en sjamaniste in. Die alternatiewe ideologieë gebruik nie wetenskaplike terminologie nie, want hulle is uiteraard antiwetenskapsideologieë. Alternatiewe praktisyns groei tans in die VSA vinniger aan as ortodokse geneeshere (Wardwell 1994). Tydens paradigmaverskuiwings word geprobeer om alternatiewe, tradisionele en selfhelpgeneeskunde in die hoofstroom van gesondheidsdienste in te trek. ${ }^{2}$ Opflikkerings van alternatiewe geneeskunde kom voor wanneer ortodokse geneeskunde, om watter rede ook al, nie meer aan die gevoelde behoeftes van 'n gemeenskap voldoen nie. Anders as voriges, het die huidige alternatiewe beweging 'n stewiger infrastruktuur en finansiële borgskappe, en mag dus langer voortduur (Yankauer 1997).

Dekades lank is daar 'n internasionale soeke na 'n nuwe mediese ("holistiese" of "biopsigososiale") model (Engel 1977) wat die eertydse antiwetenskapen antirasionaliteitsentimente aanwakker. Kommunikasie tussen leke- en professionele gesondheidswerkers word tans weer toenemend belangrik, soos met die paradigmaverskuiwings van 150 en 75 jaar gelede.

Mediese vaktaal, primêr vak- en nie taalgerig nie, is gegrond op wetenskaplik-filosofiese begrippe en nie op tradisioneel-kulturele aannames van die omgangstaal nie. Presiese woordgebruik kenmerk die eerste, en simboliese woordgebruik die tweede. Vir alle mense is hul liggaam die verwysingsraamwerk vir simboliese antropomorfismes, veral belangrik in die opkomende dissipline "transkulturele psigiatrie". Die afgelope dekade word in Engels al meer onderskei tussen disease en illness wat albei voorheen as siekte vertaal en eenders verklaar is. Die eerste word tans meer spesifiek vir 'n objektiewe patologiese entiteit gebruik, en die tweede vir 'n subjektiewe belewenis of eksistensiële ervaring van 'n siekteproses, die beste deur die Franse malaise beskryf.

Die Europese renaissance van mediese wetenskappe in die middel-17de eeu val saam met die Wes-Europese besetting van die Kaap, die "medifisering" van massas ongeletterde lyfeienes in Europa, en die ontstaan van mediese glossografieë. Jan van Riebeeck (1618-1677) was 'n tydgenoot van William Harvey (1578-1657), ontdekker van die bloedsomloop, en Antonie van Leeuwenhoek (1632-1723), uitvinder van die mikroskoop - albei baanbrekers van die mediese renaissance.

Mediese handleidings ("manuals"), 'n innovasie wat die oorwegend onge- 
letterde Europese bevolking in die elementêre beginsels van higiëne, diagnose en behandeling moes onderrig, was wesenlik verklarende terminologieë vir die nuwe mediese wetenskap. Die weiniges wat kon lees, moes die handleidings aan ongeletterdes voorlees en hulle daarin "katkiseer" met die doel om geneeskunde van sy mistiek te stroop en ongeletterde lyfeienes insig te gee in die nuwe mediese denke (Heller 1976). Voorskrifte en diagnoses was nog in Latyn, en wetenskaplike mededelings is in koerante gedoen, gewoonlik as langdradige, obskure filosofiese redenasies. Die mediese handleidings moes óók medici oortuig dat dit voordelig was dat pasiënte hulle verstaan ten einde 'n stewige bolwerk te vorm teen kwaksalwery en die uitbuiting van ongeletterde onkunde. Kwaksalwery het gedy aan die Kaap, en met inheemse magiese Koikoigeneeskunde en diverse tipes "helers" was sinvolle kommunikasie in die renaissanceparadigma onmoontlik - daarom dat die eerste (ongepubliseerde) medies-vakkundige manuskrip in Suid-Afrika juis só 'n handleiding was (Burrows 1958: 62). Trouens, Häszner (1793) haal die twee beroemdste Europese handleidings van Buchan en Tissot aan, en werp lig op medies-maatskaplike toestande aan die Kaap (Pretorius 1992).

Dokters het welvarende landhere en adellikes bedien, maar is gewantrou deur die armes wat aangewys was op selfhelpboererate en rondreisende "helers" van allerlei oortuigings. Medifisering van die breë gemeenskap begin éérs toe dokters met die armes in aanraking kom, meesal ten tye van epidemies (die Swart Dood in Europa; pokke aan die Kaap). Die middel- 17de-eeuse mediese glossografieë van Europa ${ }^{3}$ was 'n uitvloeisel van die handleidingveldtog wat geprobeer het om die kommunikasiegaping in gesondheidsdienste as gevolg van geletterdheids- en sosio-ekonomiese agterstande te oorbrug (Rosenberg 1983) - 'n taak wat weereens die Afrikaanse mediese woordeboek ten laste gelê word.

Die omvorming van armehuise tot hospitale was nog 'n groeistimulus vir 'n mediese vaktaal in Europa. Die toonaangewendes is in die akademiese sfeer ingetrek as "akademiese hospitale" van mediese fakulteite. ${ }^{4}$

Immigrantedokters, almal produkte van die renaissance in die Europese geneeskunde, het hul mediese vaktaal na Suid-Afrika saamgebring. Onder die Britse Setlaars van 1820 was daar 19 dokters wat 'n sterk akademiese invloed in die Oos-Kaap uitgeoefen het (Blumberg 1974). Duits-Joodse dokters, vanaf 1840 deur die Karoodorpgemeenskappe geassimileer, was die oorsprong van "die slim Joodse dokter" in die Afrikaanse idioom. Duitsland was toe die toonaangewende mediese moondheid (Burrows 1958: 187-188). Die Afrikaanse mediese vaktaal het uit die ingevoerde Hollandse, Engelse en Duitse vakterminologie gegroei, tale wat almal reeds die Grieks-Latynse vakterme volgens hulle eie besondere taalgebruik geassimileer het. Snyman (19883: xi e.v.) bespreek die leksikografiese aspekte daarvan.

Kommunikasie ${ }^{5}$ vorm die brug tussen abstrakte geneeskundekennis en die werklikheid van die siekbed. Die abstrakte kennis moet dáár aan elke individuele pasiënt persoonlik gekommunikeer word. Vakkennis moet uiteindelik tot 
die verstaanbaarheid van gewone taal omvorm word. Volgens die sofistikasie van gespreksgenote mag kommunikasie op drie vlakke geskied:

- interkollegiaal tussen professionele beroepsmense onderling,

- kommunaal as 'n verstaanbare een-tot-baie-oordrag van gesondheidsinligting aan verskeie taalgemeenskappe, bv. oor bedreigings (rook, alkohol, eetgewoontes), epidemiologiese inligting (malaria, VIGS, cholera) en die bekendstelling van diensmodaliteite en -gebruike (voorgeboorte-, bejaarde-, en kindersorg; private-, openbare-, en daghospitaaldienste en -benutting), en

- transaksioneel as 'n een-tot-een vakman-leek-interaksie tussen dokter-pasiënt-vennote in 'n kliniese transaksie.

Op interkollegiale vlak het elke taal maar één mediese vaktaal met vakterme wat baie spesifieke betekenisse dra om vir die wydste moontlike professionele gebruikersgroep as gesaghebbende terminologiebron en vakkundige spellys te dien. Unieke leksikografiese vereistes word aan mediese woordeboeke gestel:

Unlike editors of general dictionaries, lexicographers in scientific and technical fields are still expected to perform a prescriptive function, upholding standards of correctness and consistency. Here the problem is that the nomenclature of nearly every biomedical field is unstable. A term may have one meaning in formal usage and quite another in the jargon of practitioners. (Dirckx 1997: vi)

Woordeboeke in dié klas volg altyd éérs op die ontstaan van plaaslike geneeskundefakulteite, biblioteke en gevestigde vaktydskrifte. Twee omvattende Afrikaanse mediese woordeboeke voorsien in hierdie behoefte vir Afrikaans: Brink (1979) se verklarende woordeboek (WAG) en Snyman (19883) se vertalende woordeboek $(\mathrm{GW})$, respektiewelik produkte van mediese fakulteite gestig aan die Universiteit van Stellenbosch (1956) en die Universiteit van Pretoria (1948). Hul gewildste eweknieë is dié van Dorland $\left(1864 ; 1994^{28}\right)$ en Stedman (1911; $1995^{26}$ ). Deurlopende hersiening, bywerking en vertolking van internasionale vakterminologiewoordeboeke (soos gehanteer deur hul nasionale universiteite) besorg aan hierdie woordeboeke internasionale gesag en aansien. Butterworths Medical Dictionary (MacNalty 19653' v-xii) verklaar eksplisiet dat 'n land se akademiese departemente gewoonlik samestellers lei in hulle hanteringswyse van internasionale vakterminologiese voorstelle. $\mathrm{Na}$ 'n meningsopname onder sy gebruikers besluit die jongste SMD (199526: vi) om van sy 92 jaar lange gebruik van Latynse terme (NA) af te sien en oor te skakel na Engels (BR) ${ }^{6}$. Vakterminologiese hersiening en bywerking van farmaseutiese, bakteriologiese, chemiese en psigiatriese terme word gebaseer op óf amptelike farmakopeë of standaardteksboeke óf, in geval van die psigiatriese terminologie, DSM-III-R (Diagnostic and Statistical Manual of Mental Disorders, derde hersiening, 1987). 
Die PW val egter in die kader van beknopte, spesifiek-gerigte woordeboeke ingestel op 'n breë, ongedefinieerde gebruikersgroep, soos Van der Merwe en Louw (1935) se Mediese Woordeboek (met inbegrip van Veeartsenykundige, Tandheelkundige en Hospitaal-benaminge), Hansen (1962) se Beknopte Mediese Woordeboek/ Concise Medical Dictionary, en Rompel (1975) se Nurses' Dictionary English-Afrikaans/Verpleegsterswoordeboek Engels-Afrikaans. Die ongedefinieerde gebruikersgroep word nogtans taamlik homogeen omskryf:

by Van der Merwe en Louw (1935: I):

"verpleegsters en professioneel opgeleide persone wat vakkundige stukke in Afrikaans wil vertaal of wat in Afrikaans oor geneeskundige onderwerpe wil skrywe of lesings wil hou", asook "nie-vakkundiges" wat "Engelse stukke in Afrikaans" wil "oorsit",

(Daar was destyds nog slegs twee Engelstalige mediese fakulteite in die land.)

by Hansen (1962: vii):

"verpleegsters, hulp-geneeskundiges, noodhelpers en alle ander persone wat basiese geneeskundige terme magtig moet wees", en

by Rompel (1975: Preface):

benewens die "nurses" van die titel, ook "medical auxiliaries, first-aiders, medical secretaries, and all others who require a knowledge of basic medical terms".

Sowel Hansen as Rompel erken die hulp van die Taalkomitee, Fakulteit Geneeskunde, Universiteit van Stellenbosch. Dié drie beknopte woordeboeke het elk minder as 10 000, sowat 'n kwart van die trefwoordinskrywings in WAG (1979) of GW (19883). Selfs nóg korter en meer spesifiek gerig tot niemediese fisiologiestudente is die glossarium (469 fisiologiese vakterme) agter in die fisiologieteksboek van Meyer en Meij (1987) (vermeld in die PW se bronnelys). Rompel (1975) het minder trefwoorde (4 709) as die PW (6 865), maar vertaal veel meer klinies-diagnostiese terme as die PW. Die PW, anders as sy twee voorgangers, is egter verklarend en nie slegs vertalend nie.

Mediese joernalistiek gedy tans, met 'n eiesoortige behoefte aan verklarende woordeboeke. Nederlandse studies bevind dat $90 \%$ koerantberigte een of meer foute bevat, en ongeveer die helfte tydskrifte publiseer onnoukeurige sensasionele artikels — 'n eenderse situasie as in Suid-Afrika (Brummer 1986).

Die mediese vaktaal brei letterlik astronomies uit:

Adepts of the Big Bang theory will recognise that if the exponential increase seen in the decades 1950 through 1970 continues, then some 
time during the next century Index Medicus will be growing faster than the generally accepted rate for the expansion of the universe. (Taylor 1992)

Daar is sowat 1350 mediese fakulteite in die wêreld (126 in die VSA, 8 in SuidAfrika) waar die meeste professionele vaktaalgebruikers opgelei word, met nuwer kategorieë hulppersoneel veral aan technikons.

\section{Die Paramediese Woordeboek}

\section{$2.1 \quad$ Titel}

Die enigma van die titel wentel om uitkenning van die teikengebruikers: Is dit bedoel vir "beroepsgroepe aanvullend tot geneeskunde" ("professions allied to medicine"), of "aanverwante beroepe" (WAG)? Is daar sprake van 'n nuwe mediese terminologie, benewens die gebruiklike? Die werk se enigmatiese titel hou ook verband met sy inhoud.

In die 1960's al het verpleegkundiges, ten regte, beswaar gehad teen die beroepsaanduiding "paramedies" vanweë hul integrerende rol in gesondheidsberoepe. Die term verwys, vanaf die 1970's, plaaslik én internasionaal, toenemend na 'n spesifieke beroepsgroep, die "paramedici", wat ambulanspersoneel, spesifiek vir noodsituasies opgelei, aandui. Die Suid-Afrikaanse Geneeskundige en Tandheelkundige Raad (SAGTR) registreer paramedici onder die omvattende beroepsgroep "noodsorgbemanning" ("emergency care personnel"), met subkategorieë ambulansnoodpersoneel en -assistente, basiese ambulansassistente, operasionele noodsorgordonnanse en noodsorgassistente - slegs één van 12 "aanvullende" professionele beroepsgroepe (SAGTR, 1997). Engelse woordeboektitels is duideliker, bv. Medical and Allied Health Dictionary (19973).

Die PW definieer paramedies soos volg:

wat een of ander verband met die mediese wetenskap het; aanvullend tot geneeskunde in die handhawing en herstel van normale gesondheid (paramediese werkers sluit in terapeute, verpleegpersoneel, geneeskundige maatskaplike werkers, ambulanspersoneel, aptekers, dieetkundiges, ens.).

Die pleonastiese taakomskrywing "herstel van normale gesondheid" vra by implikasie wat "abnormale" gesondheid is. Die lys paramediese vakgebiede, op die agterblad en in die eerste sin van die Voorwoord herhaal, lys dáár ook "skoliere met biologie as vak" en "studente van anatomie en fisiologie". 'n Meer beskrywende titel kon Skoolwoordeboek van Anatomiese en Fisiologiese Terme gewees het - ' $n$ vermoede bevestig deur die inhoud en bronnelys (p. 288-289) waar 24 van die 30 gelyste bronne boeke is wat op skoolvlak gebruik mag word. Vir terapeute, onder die dosyn aanverwante professies van die SAGTR, is daar min 
vakeie terme. Tandheelkundige terme word wel ruim gedek. Vir paramedici sou, onder meer, terme soos anabiose, binneaarse oorgieting, resussitasie, kardioversie, en verskeie tipes spalke, lugweë en draagbare verwag word, maar behalwe binneaars is geeneen opgeneem nie.

Die verwysing na paramediese terme verdiep dus die enigma: Watter terme word na dié kategorie gedelegeer? Dat "dit bykans onmoontlik (is) om alle terme wat in die paramediese veld bestaan, in 'n woordeboek te vervat, aangesien dit so 'n wye veld dek", soos die outeur in die Voorwoord sê, werp geen lig op die keuringskriteria of -werkswyse wat wel vir seleksie gevolg is nie. Hoe kwalifiseer die ongewone cholemie vir opname ten koste van bv. die meer dikwels gebruikte, maar weggelate choledochus, -sistitis of -sistektomie? Of waarom word hidrotoraks en -kefalus opgeneem, maar nie hidronefrose nie, of hematofaag en -blast, maar nie hematemese of melena nie? Die suggestie van 'n afsonderlike terminologie vir die paramediese veld is baie verwarrend:

Although each profession and specialty area has its own precise terminology, most health workers share a single vocabulary. (Smith en Smith 1986: ix)

Die seleksie móét deur praktisyns aktief in die betrokke beroep gedoen word. Dit vereis 'n seleksiepaneel as die teikengroep verskeie dissiplines omvat. Tensy gedoen deur praktisyns met "strong backgrounds in scholarship and practice in their respective fields" (Dirckx 1997: vi ), kan skerp kritiek verwag word soos destyds met resensies van Mönnig, Van der Merwe en Louw (1944) en Boshoff (1953) gebeur het. Die kritiek was afkomstig van dosente van vergelykende anatomie, embriologie en veeartsenykundige anatomie (óók paramediese dissiplines?). Die voorkeur vir vertalings na Afrikaanse omgangstaalwoorde en verafrikaansings en neologismes was onaanvaarbaar. Grobbelaar ${ }^{7}$ (1954) lys enkeles waaronder gorrel ("trachea"), hooflugpyp ("bronchus") en lug(pypie)blaas, asemlugpypie ("alveolar bronchiole"), en terminoloë se langer en moeiliker spelbare verafrikaansings bv. wandgataskruispunt ("obelion"), vrugpisuitleiergroef ("urethral groove") en saaddiertjie ("spermatozoon").

Omgangstaalterme ingebou in verklarings kan duidelikheid vir 'n lekeleser bring, en die PW maak ruim hiervan gebruik: Akkuraat-beskrywende, gewone omgangstaalwoorde mag eventueel in 'n toekomstige "woordeboek vir primêre gesondheidsorg" tereg kom bv. sluitspier vir sfinkter, slukbeswaar vir disfagie, en strekspiere en buigspiere vir ekstensors en fleksors. Die ou strewe om geneeskunde te demistifiseer mag só verwesenlik, en gelatiniseerde begrippe vir die leek verstaanbaar gemaak word soos deur die eertydse "handleidings" beoog. Die opname van ongewone en ongebruiklike Nederlandse terme soos eetsel vir fagosiet of vleëlgewrig vir los gewrig moet egter liefs vermy word. 'n Titelwysiging na iets skerper gefokus op identifiseerbare teikengroepe mag van die PW 'n baanbreker maak, met natuurlik streng keuring van terme vir ('n) gedefinieerde teikengroep(e). Moontlike titelwoorde is primêre gesondheidsorg, 
mediese leketerme, selfs geneeskundeterme, in die lig van die agterbladaanduiding na "in besonder vir die gewone mens".

\section{$2.2 \quad$ Voorwoord}

Die PW, die werk van 'n enkelouteur, bedank by name individue van die Nasionale Terminologiediens, en meld 'n ontstaansgeskiedenis van vyf jaar. Die verwysing na "min vakliteratuur (wat) in Afrikaans beskikbaar is", is klaarblyklik relatief tot wat voldoende geag word, maar is tog betwyfelbaar. Daar is tans Afrikaanse mediese teksboeke op voor- en nagraadse vlak in byna elke spesialiteitsgebied van genees- en verpleegkunde beskikbaar, sommige met verskeie oplaes. ${ }^{8}$ Verskeie vakgerigte Afrikaanse woordeboeke bedien die (mediese) basiswetenskappe (chemie, biologie, fisika, statistiek en rekenaarterminologie) en prekliniese wetenskappe (aptekerswese). Insluiting van soveel van hierdie terme in die PW neem onnodig ruimte in beslag wat beter benut kon gewees het.

"Dit is juis die behoefte aan eenvoudige verklarings, waaraan geneeskundige woordeboeke nie aandag gee nie," sê die outeur in die Voorwoord, "wat gelei het tot die samestelling van hierdie woordeboek." Hierdie beweegrede (ter wille van skoliere met biologie as vak?) word deur verskeie definisies weerspreek wanneer hulle bv. met dié in WAG vergelyk word:

\section{omentum}

'n vou of verlenging van die peritoneum wat óf vry óf as verbinding tussen twee organe in die buikholte strek (PW)

Dubbele laag peritoneum wat tussen twee buikorgane strek (WAG)

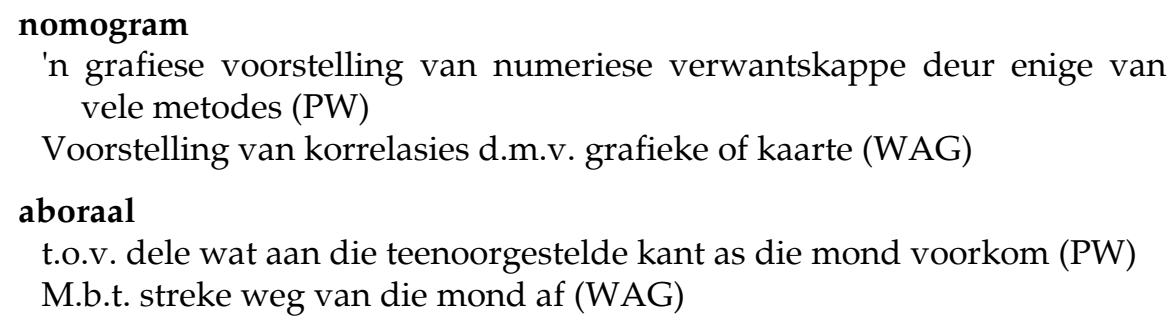

'n grafiese voorstelling van numeriese verwantskappe deur enige van vele metodes (PW)

Voorstelling van korrelasies d.m.v. grafieke of kaarte (WAG)

\section{aboraal}

t.o.v. dele wat aan die teenoorgestelde kant as die mond voorkom (PW)

M.b.t. streke weg van die mond af (WAG)

"Die skryfwyse van terme het heelwat probleme opgelewer vanweë uiteenlopende beskouings en beperkte Afrikaanse bronne," beweer die outeur verder in die Voorwoord. Veertig jaar gelede was so 'n stelling korrek, maar is tans kennelik onjuis. Die Afrikaanse vaktaal geniet reeds nasionale en internasionale erkenning en voorsien in alle vaktaalbehoeftes, soos onder meer blyk uit die gebruik daarvan in die Suid-Afrikaanse Mediese Joernaal (SAMJ), ${ }^{9}$ lyfblad van die Mediese Vereniging van Suid-Afrika (MVSA). Die internasionale Index Medicus dui reeds sedert 1966 (vertaalde) titels van Afrikaanse mediese artikels aan met (Afr.) agterna. Die SAMJ, 'n internasionaal gesiene vaktydskrif, dikwels in die 
Citation Index vermeld, is steeds tweetalig (soos ál die MVSA se publikasies). Afrikaans verskyn in amptelike stukke van die statutêre Suid-Afrikaanse Geneeskundige en Tandheelkundige Raad (SAGTR). 'n Groot aantal Afrikaanse verwysingsbriewe met 'n redelik vaste skryfwyse van terme word daagliks tussen medici en ander beroepsgroepe gewissel. Professionele gesprekke, voordragte, en populêre tydskrifte benut vakterme vrylik en verstaanbaar. Drie Afrikaanse mediese fakulteite gebruik daagliks Afrikaans as onderrigtaal van honderde studente, en notas in Afrikaans word uitgedeel.

Daar is by Afrikaanssprekendes wel 'n ontoepaslik puristiese gevoeligheid oor alternatiewe spellings van woorde. Soos Snyman (19883: xiii) uitwys, is die verskille tussen Engels en Anglo-Amerikaans groter: Stedman (199526: xx) vermeld gevalle waar Engels die alfabetisering van Anglo-Amerikaanse trefwoorde raak, en gee hulle dan aan met 'n kruisverwysing na die gebruiklike AngloAmerikaanse spelvorm. Die Engelse $a e$, oe en ou word in Anglo-Amerikaans $e, e$ en $o$ onderskeidelik, sodat naas aetiology, oedema en tumour ook etiology, edema en tumor bestaan. Alhoewel die PW deurgaans slegs -ien- en nie -ine- vorme gee nie, word naas urien en vitamien tog urine en vitamine gegee wat as normale wisselvorme nie (meer) steurend is nie. Aangesien ook slegs-ied-en nie-ide-vorme opgeneem word nie, is dit daarom vreemd dat piramied nie ook as normale wisselvorm van piramide gegee word nie.

\subsection{Konstruksie (Ordening)}

Naas die Voorwoord en die Bronnelys vermeld die inhoudsopgawe van die PW die volgende: Verduidelikende aantekeninge by die hooflys, Hooflys Afrikaans-Engels (met verklarings in Afrikaans), Verduidelikende aantekeninge by die glossarium, Glossarium (Engels-Afrikaans), Voor- en agtervoegsels, Griekse en Latynse stamme, afleidings en verbindingsvorme.

2.3.1 Die aantekeninge verduidelik die gebruik van die samestellingsmetodiek, verskillende hakies en afkortings, en die manier van aanduiding van sinonieme, kruisverwysings, meervoudsvorme en verkleiningsvorme.

In die verduidelikende aantekeninge by sowel die hooflys as die glossarium kom ongeveer dieselfde inskrywing ten opsigte van trefwoorde voor. Die een wat die hooflys voorafgaan, lui:

Trefwoorde met dieselfde spelling maar verskillende betekenisse word genommer om kruisverwysing te vergemaklik, byvoorbeeld:

suture $^{1}$ steek suture $^{2}$ hegdraad

(Terloops: suture se vertaling "beennaat (tussen skedelbene)" is nie opgeneem nie.)

Dié inskrywing hang saam met die volgende verduidelikende aantekening wat 
die glossarium voorafgaan:

Waar die Engelse trefwoord op verskillende woordsoorte dui, word dit aangedui, byvoorbeeld:

block $^{1}$ n. blok

block $^{2}$ v. blokkeer, onderdruk

Alhoewel dit miskien kruisverwysing vergemaklik, is die gebruik van verhewe syfers ongewoon en verwarrend omdat dit die verskil tussen homonimie, polisemie en funksiewisseling ophef (toegegee dat woordsoortverskille óók deur afkortings soos $\mathbf{n}$. en $\mathbf{v}$. aangedui word). In die glossarium sou ' $n$ mens eerder die volgende inskrywing verwag:

suture 1 steek 2 hegdraad

In die hooflys kom die volgende voor:

steek $^{1} \mathbf{n}$. suture hegting met naald en gare

steek $^{2}$ n. stitch skielike skerp pyn, soos bv. miltsteek

steek $^{3} \mathbf{v}$. stab deurboor met 'n skerp voorwerp

In Afrikaans is dié drie inskrywings etimologies verwant. Verhewe syfers sou miskien wel gebruik kon word om steek ${ }^{3}$, die werkwoord, van steek ${ }^{1}$ en steek $^{2}$, die selfstandige naamwoorde, te onderskei, maar steek ${ }^{1}$ en steek $^{2}$ hoort saam:

steek $^{1} \mathbf{n} .1$ suture hegting met naald en gare $\mathbf{2}$ stitch skielike skerp pyn, soos bv. miltsteek

steek $^{2}$ v. stab deurboor met ' $n$ skerp voorwerp

Die samehang tussen brug$^{1}$, brug $^{2}$, brug $^{3}$ en brug $^{4}$ sou baie duideliker deur slegs ' $n$ enkele inskrywing soos die volgende getoon kon word:

brug bridge 1 . kyk pons. 2 beenagtige verhewendheid van die neus 3 middelste deel van die voet 4 smal weefselstrook

Dit geld óók vir, onder meer, die vier afsonderlike inskrywings elk van balans, basis en bors.

Dat die verwysingstegniek wat in die PW gebruik word, nie noodwendig so duidelik is nie, blyk uit die inskrywings substraat ${ }^{1}$, substraat ${ }^{2}$, substratum ${ }^{1}$ en substratum ${ }^{2}$. By substratum ${ }^{1}$ word gesê: . kyk substraaț , maar die gebruiker moet dan self agterkom dat die verwysing sowel substraat $^{1}$ as substraat $^{2}$ insluit. (Terloops: slegs substraat ${ }^{1}$ se verklaring is die aanvaarde; substraat $^{2}$ is 'n ongewone sinoniem vir kweekbodem ("culture medium") wat nie opgeneem is nie.)

Die gebruik van kruisverwysings is een van die tegnieke om terme wat saamhoort en vanweë die alfabetiese ordening dwarsoor 'n woordeboek versprei word, weer bymekaar uit te bring. Die aanwending van diagramme en tabelle is ' $n$ ander. Meyer en Meij (1987) gebruik die periodieke tabel ruimte- 
besparend om ál die inligting oor elemente op 'n enkele bladsy (Bylae $x$ ) aan te gee, in plaas van inskrywings onder al die letters van die alfabet - 'n gebruikersvriendelike aanbieding wat óók vir ander mediese woordeboeke aanbeveel kan word. Maar daar moet in ag geneem word dat 'n woordeboek soos die PW slegs dié elemente sal lemmatiseer wat medies van belang is.

2.3.2 Met "selection means rejection" beklemtoon Dirckx (1997: iv) die moeilike insluitingskeuring. Verskeie alledaagse terme (soos binneoor, bal-en-potjie-gewrig, bloedbank) word ewe goed in algemene verklarende woordeboeke (bv. VAW, $\left.1993^{8}\right)$ gehanteer. Vakwoordeboeke sluit doelbewus "gewone" of "selfverklarende" woorde uit, maar die kriteria van "gewoon" of "selfverklarend" is onduidelik. Rompel (1975) se voorbeelde is bed, intemperance en integrity; Brink s'n gesweldheid, haakvormig en inasem.

Daar is 'n aansienlike aantal gewone selfverklarende Afrikaanse woorde wat in gesondheidsverband gebruik word, moontlik as gevolg van 'n lang geskiedenis van selfhelpvolksgeneeskunde en 'n tekort aan vakkundiges, en dalk ook bevorder deur voubiljette in Hollandse medisynekiste en oornames uit ander tale. Miskien is daar behoefte aan 'n verklarende mediese woordeboek van leketerme om uniforme begrip aan sommige te verleen (bv. aan die Kaap, was "menstrueer"). Dit is belangrik vir transaksionele kommunikasie in die praktyk, veral in die lig van die huidige klem op primêre gesondheidsorg ${ }^{10}$.

Die PW sluit aambeeld, hamer en stiebeuel (die oorbeentjieketting) in, maar laat bv. aambei, bloedvint en maagwerkings weg. Jig word, baie noodsaaklik, gedefinieer, want die meeste Afrikaanssprekendes gebruik dit verkeerdelik as versamelnaam vir álle gewrigsontstekings. Besonder baie gewone woorde word slegs vertaal in die PW en na meer vakkundig-gebruiklike terme kruisverwys bv. dodelik, dokter, eier, eiland, lug, lugleegte, neerslag, spuug, steen en wang. Hulle het plek in definisies maar nie as trefwoorde in die hooflys nie. Seer word vertaal as sore, en verklaar as "pynlike plek aan die liggaam", dog nie óók as "seerplek", "ulkus", "wond" of "bedseer" nie — 'n voorbeeld van die inherente dubbelsinnigheid van leke- teenoor vakgedefinieerde woordgebruik.

2.3.3 Die voor- en agtervoegsels, Griekse en Latynse stamme en afleidings en verbindingsvorme in die afsonderlike lys kon, myns insiens, gebruikersvriendeliker in situ op hul alfabetiese plek in die hooflys opgeneem gewees het. Met 37 trefwoorde in die hooflys wat met peri- begin, 17 met para-, 24 met anti- en 44 met epi- (altesaam 122), sal 'n enkele verklaring van die voorvoegsel gebruikersvriendeliker wees aan die begin van sulke lang lyste. In die plek van hierdie afsonderlike lys (p. 276-287) sou 'n saamgegroepeerde lys afkortings, asook akronieme en eponieme, 'n belangriker probleem van die mediese vaktaal, nuttig gewees het. Vreemde woorde se betekenis kan wel nog in 'n bepaalde konteks geantisipeer word, maar akronieme en eponieme het geen onderliggende logika nie - trouens, akronieme se letters word juis gerangskik om maklik op die tong te lê. Eponieme van toetse en reagense wat vandag nie meer in die 
kliniek teengekom word nie (bv. Benedict-reagens en Benedict-toets), kon weggelaat gewees het.

Homeo-, homo-, en homoio- word in dié lys as sinonieme gegee met betekenisse "eenders, onveranderlik, dieselfde, net soos", maar vakkundig-terminologies word tóg tussen hulle onderskei. Homeo- slaan spesifiek op eenders (soos in homeopatie, homeostase) en homo- spesifiek op dieselfde (soos in homosigoot, homoniem, homofiel). Homopaat en homostase het nie bestaansreg as vakterme nie. Die eenderse definisies, albei gelys in die PW, kyk die verskil tussen die dinamiese eenders en statiese dieselfde mis; die Grieks is respektiewelik homoios "eenders" en homos "dieselfde".

Gebruikersonvriendelik beskryf die konstruksie van die PW.

\subsection{Definisies (Verklarings)}

Kenmerkend van definisies in vakwoordeboeke is hul noodsaaklike voorskriftelikheid (Dirckx 1997: vi). Sommige van die PW se "eenvoudige verklarings" bots egter met die aanvaarde begrip en gebruik in die vakterminologie. By aborsie word 'n embrio (en nie 'n fetus nie) uitgewerp, en parturisie is die skeiding van 'n fetus (en nie 'n embrio nie) van sy moeder. Embrio en fetus word korrek as, respektiewelik, "die eerste twee maande van ontwikkeling", en "'n menslike embrio na agt weke van intra-uteriene ontwikkeling" verklaar. Paring ("copulation") is seksuele omgang tussen twee heteroseksuele mense, soos korrek onder koïtus (met ses sinonieme) verklaar, maar nie tussen "chromosome tydens meiose nie"; die "homoloë chromosome" se "aantrekking na mekaar" word beter as afparing beskryf.

'n Ontoereikende verklaring kom voor by abdominopelviese holte (holte inferior tot die diafragma) wat identies met abdominale holte beskryf word; laasgenoemde sluit óók die bekkenholte in, terwyl eersgenoemde die holte tussen die borskas en die bekken is. Opvallende feitefoute is: Addison-siekte is 'n tekort aan bynierskorshormone, en nie aan adrenokortikotrofiese hormone nie; aldosteroon is beslis nie (soos beklemtoon met veral) 'n adrenokortikotrofiese hormoon nie, maar 'n bynierskorsmineralokortikö̈ed (soos korrek onder aldosteroon verklaar). Onder $\mathbf{p H}$ word twee afsonderlike, en verwarrende verklarings van die enigste definisie van $p H$ gegee: $\mathrm{pH}$ (akroniem vir power of $\mathrm{H}+$ ) is 'n simbool vir die negatiewe logaritme van waterstofioonkonsentrasie (uitgedruk as mol per liter) en aangegee in eenhede (en nie uitgedruk as mol per liter nie!). (Terloops, $\mathrm{pH}=7$ is slegs neutraal by ' $\mathrm{n}$ temperatuur van $22^{\circ} \mathrm{C}$; by liggaamstemperatuur $\left(37^{\circ} \mathrm{C}\right)$ is die neutrale punt 6.8 .)

'n Ontlening soos vleëlgewrig uit Nederlands bly, selfs met behulp van HAT en VAW, onverstaanbaar. WAG vertaal flail joint ondubbelsinnig met los gewrig. Sweserik (soetvleis) wat as sinoniem van timus gegee word, kon net in HAT en VAW gevind word waar dit as sinoniem van pankreas (alvleisklier) voorkom. 
Dalk verskuil "paramedies" in die titel die weglating van verskeie siektename en kliniese definisies, as synde medies eerder as paramedies! Porfirien, die pigment, word verklaar, maar nie die siekte porfirie nie. (Suid-Afrika het die hoogste voorkoms daarvan ter wêreld; Suid-Afrikaanse navorsers het beduidend tot die wetenskaplike kennis en kliniese klassifikasie bygedra.) Bepaalde "paramediese gebruikers" (mediese sekretaresses, verteenwoordigers en joernaliste) sal dalk juis kliniese definisies van siektename en sindrome in die woordeboek soek (hematemese, melena, hemoptise ens.) om die diagnoses waarmee hulle te make het, te verstaan (en korrek te spel!) - afhangende natuurlik van hoe "paramedies" verstaan word!

Die inkonsekwente gebruik van byvoeglike naamwoorde is steurend by gevalle van endokriene hiperfunksie: by Conn-sindroom is daar 'n buitensporige, by Cushing-siekte 'n oormatige en by Cushing-sindroom 'n oortollige hormoonsekresie. Daar is subtiele verskille tussen hulle. Oormatig is die mees toepaslike; buitensporig is meer gebruiklik in die sin van "baie meer as wat nodig is", en oortollig in die sin van "meer as wat nodig is". Omdat hormoonvlakke normaalweg 'n wye reikwydte het, beskryf buitensporig en oortollig, myns insiens, die betekenis minder akkuraat as oormatig. Aan watter een egter voorkeur verleen word, dit móét immers konsekwent gebruik word.

'n Hinderlike gebruik is om woordgroepe bestaande uit byvoeglike plus selfstandige naamwoorde, alfabeties onder eersgenoemde te plaas: daar ontstaan gevolglik afsonderlike inskrywings ver uitmekaar (bv. anatomiese, fisiologiese en (weggelaat) chirurgiese dooieruimte i.p.v. dooieruimte 1, 2 en 3 . By dooieruimte, die kernbegrip, word anatomiese en fisiologiese dooieruimte nie vermeld nie.

Die verouderde terme innominaat arterie en innominaat been is nie opgeneem nie, maar vir eersgenoemde word onbenoemde slagaar in plaas van die huidig gebruiklike bragiosefaliese arterie opgeneem en verklaar, terwyl vir laasgenoemde die tans korrekte os coxae opgeneem is en na koksiks verwys word waar die verklaring voorkom.

\subsection{Spelling}

Solank algemene Afrikaanse woordeboeke (VAW 19938, HAT 19943; AWS 19918, en die South African Multi-Language Dictionary and Phrase Book 1991) steeds diftonge soos die dubbel-r in diaree gebruik, en die voorgestelde spelwyse van vaktaalwoordeboeke (WAG 1979 en GW 1988³) ignoreer, sal spelonsekerheid bly voortbestaan. GW, hieronder volledig aangehaal, gee suiwer beredeneerde riglyne vir die spelling van Afrikaanse vakterme. Die spelreëls van die AWS (1964) het óók vir WAG as grondslag gedien by die spel van Afrikaanse terme, maar waar dit egter nie altyd uitsluitsel kon gee nie, "is ander gesaghebbende Afrikaanse bronne gebruik" (Snyman 19883: x): 
Die groot behoefte by die Afrikaanse weergawe, veral wat terme uit Grieks of Latyn betref, is om dit morfologies korrek maar so bondig en beeldend moontlik te stel. Met die inlywing van Griekse of Latynse woordwortels in Afrikaans dra die betekenis van die oorspronklike woord besondere gewig. ... Diftonge is dus tot een fonetiese letter verminder, en die verbindings-r of -1 verkieslik weggelaat bv. diarrhoea is saamgestel uit:

$$
\text { dia - deur rhein - vloei. }
$$

In die Griekse spelling is 'n verbindings-r volgens hul fonetiese benadering ingevoeg. In Afrikaans is die dubbel-r beide oorbodig en verwarrend. ... Ons spel dus die woord diaree.

Dieselfde geld vir die volgende voorbeelde:

$$
\begin{aligned}
& \text { menorrhoea - menoree } \\
& \text { otorrhoea - otoree } \\
& \text { haemorrhage - hemoragie } \\
& \text { allorrhythmia - alloritmie. }
\end{aligned}
$$

'n Woord soos papilloma bestaan uit papil en -oma. Ons spel dit dus papiloom. Dieselfde geld vir die ander afleidings en samestellings van papil. Ook tonsil met sy afleidings het 'n oorbodige 1 wat weggelaat kan word, bv. tonsillitis: tonsilitis in Afrikaans. (Snyman 19883: xi)

Met die uitsondering van diarree, spel die PW hemoragie en alloritmie korrek met een $r$, maar bevat nie die ander in bogenoemde lys nie. Die beginsel word wel gehandhaaf wanneer omfaloree met 'n enkele $r$ gespel word; maar ongelukkig word die verklaring van omfaloragie dáár aangegee! Die spelling van tonsilitis sluit egter nie hierby aan nie: dit word met 'n dubbel-1 opgeneem.

\section{Toekomsperspektief op mediese woordeboeke}

Die toekoms van Afrikaanse mediese woordeboeke sal ongetwyfeld dieselfde wees as dié van mediese woordeboeke oor die algemeen, en almal van die uitkoms van internasionale rigtingsoekende neigings en eksperimente met vaktaalwoordeboeke in die heersende era van paradigmaverskuiwings.

Die Nasionale Terminologiediens het kennis geneem van die hoë nasionale prioriteit op primêre gesondheidsorg en die dringende terminologiese behoefte, en 'n veeltalige publikasie word saamgestel (Jordaan-Weiss 1995), skynbaar met die doel om interkollegiale kommunikasie te bevorder. Die formele wetenskaplike onderrig van geregistreerde beroepslui geskied steeds in één van die wetenskapstale van Suid-Afrika, en gevolglik word probleme op daardie vlak nie voorsien nie. Dalk kan 'n kommunikasieleemte ontstaan as alternatiewe geneeskunde in die breë dienslewering betrek word. Die ter plaatse opleiding en gebruik van tolke in klinieke was ten spyte van groot leemtes tot dusver tog 
taamlik bevredigend vir transaksionele kommunikasie in Suid-Afrika, maar in 'n Kanadese eksperiment ${ }^{11}$ was stetoskoop bv. nie vertaalbaar nie, omdat die enigste Ojibwawoord vir luister beteken "om na die hele persoon te luister", en nie na sy spesifieke anatomiese dele nie! (Rafuse 1993). Kommunale kommunikasie is waarskynlik die hoër onmiddellike prioriteit in Suid-Afrika, juis om die veranderde klem en betekenis van primêre gesondheid sinvol te verduidelik.

Daar is toenemende voorkeur vir gewone taal in mediese woordeboeke en die PW, onder meer "vir die gewone mens" bedoel, steek sy kleim hier af. Die voorkeurverskuiwing van Latyn na Engels vir anatomiese terminologie is nóg 'n wyse waarop die aandrang op demistifikasie van geneeskunde met eenvoudige, maklik verstaanbare omgangstaalekwivalente tegemoet gekom word. Namate die paradigmaverskuiwing op dreef kom, ontplooi daar 'n ál wyer gesondheidsgesprekskring. 'n Bydraende faktor tot negatiewe kritiek op die PW lê by die ongelukkige feit dat die omvattende Afrikaanse verklarende woordeboek (WAG, vermeld in die PW se bronnelys) nie sedert sy verskyning hersien of bygewerk is nie. Die groei van nuwe terme word gebalanseer deur die aanwas van Afrikaanse mediese vakkundiges, wat onderleg in die immunologie, molekulêre biologie en genetika, sekerlik by hierdie groeipunte van die mediese terminologie ingespan kan word. Die hersiening en bywerking van WAG, en sowel die herdefiniëring as uitdunning van argaïese, ongebruiklike terme móét deurlopende en dringende aandag geniet, net soos by sy Engelse eweknieë reeds aansienlik lank (92 jaar by SMD en 130 jaar by DIM) gebeur. Die heraktivering van 'n taalkomitee soortgelyk aan dié van destyds, verkieslik saamgestel uit al drie Afrikaanse mediese fakulteite, is gebiedend noodsaaklik om terminologiese koers aan te dui tydens die onstabiele oorgangsfase na 'n nuwe kommunikasiestyl. Dit is wenslik om, soos die jongste internasionale mediese vakwoordeboek (SMD 1995: vi) doen, hoëprofielterme, beskryf as "terms (which) have so profoundly altered the way medicine is practised and consumed that they warrant more than the standard dictionary definition", te identifiseer en ruim toe te lig. Daar word 125 sodanige terme gedefinieer, en (in die alfabetiese lys) tussen dik groen horisontale lyne aangedui. 'n Omvattende standaardwerk behoort die gesaghebbende bron te bly waaruit dissiplinegerigte medewerkers deurlopend uittreksels en wysigings na behoefte kan maak ten einde begripsuniformiteit vir die vaktaal te verseker.

Die paradigmaverskuiwings sal waarskynlik nie soseer nuwe terminologie- as nuwe gebruikersbehoeftes skep nie. Die behoefte aan veeltalige mediese woordeboeke met eenvoudiger, alledaagse verklarings sal aanvanklik, soos in die geval van die PW, klaarblyklik op skoliere gerig wees, met vrylike gebruik van omgangstaal in die definisies van vakterme (kieliebeen, ontwater, oorspeekselklier, streepliggaam ens. in die PW) — 'n gebruik wat kommunikasie op primêre gesondheidsvlak sal bevorder. Dit sal enersyds die demistifikasie en verduidelikende doel van die 18de-eeuse mediese lekehandleidings en glossografieë soos dit tans weer op die voorgrond kom, in die 21ste eeu voortsit. Die eras is vergelykbaar ten opsigte van heersende onderwysagterstande, sosio-ekono- 
miese ongelykhede, en wisselende sofistikasievlakke, in groot dele van die huidige (derde)wêreldbevolking (insluitend Suid-Afrika). Die aandrang klink die luidste juis in daardie gebiede waar die grootste verskille is, en die derde wêreld vorm drie kwart van die totale mensetal.

Die wêreldwye verandering in gesondheidsdienste is dinamies, en daar moet bygebly word by vordering ten opsigte van geletterdheid, leesvaardigheid, en snelstygende sofistikasievlakke onder agtergeblewenes wat daarop sal volg. 'n Hoër sofistikasievlak is reeds merkbaar onder staatshospitaalpasiënte. Mediese joernalistiek se (onversadigbare) behoefte aan artikels oor mediese sake gaan dikwels gepaard met 'n verduideliking van onderliggende teoretiese en fundamentele beginsels. Eerstetaalsprekers kommunikeer gemaklik met pasiënte uit hul eie taalgroep omdat die omgangstaal ook hul spreektaal is, maar anderstaliges is nie noodwendig vertroud met ekwivalente vir vakkundige terme in die gewone taal nie. In 'n groot akademiese hospitaal se buitepasiëntafdeling is dit opvallend dat Afrikaanssprekende pasiënte vandag tegniese en diagnostiese terme soos hipertensie, diabetes, anemie, kardiogram en rekenaartomografie gemaklik (en korrek) gebruik in teenstelling met dieselfde pasiëntbevolking en hospitaal 'n paar dekades gelede (eie waarneming). Met die werklas beter versprei tussen gemeenskapsklinieke en daghospitale sal professionele gesondheidswerkers dalk meer tyd bestee aan, en klem lê op, die mentor-aspek van gesondheidsorg.

Die ontplooiende paradigma verskuif ook interkollegiale behoeftes en gebruike. Die inhoud van plaaslike vakkundige tydskrifte het van oorwegend gevallestudies na byna uitsluitlik oorspronklike hoogs gespesialiseerde navorsingsartikels en terapeutiese proewe verskuif. Eersgenoemdes, veral gerig op 'n groot Afrikaanssprekende praktisynsgroep, het geleidelik geswig voor laasgenoemdes met, as teikengroep, 'n klein internasionale eliteleserskring van hoogs gespesialiseerde vakkundiges. Afrikaanse artikels in die SAMJ het radikaal afgeneem soos gespesialiseerde vakkundigheid toegeneem en Afrikaanssprekendes deskundige navorsing begin onderneem het. Prof. Daniel J. Ncayiyana (1998), redakteur, haal Mathews Phosa (Zuid-Afrika, Des. 1997) aan oor die gebruik en groei van Afrikaans: "Dis hoe 'n taal groei - hy moet gepraat word, geskryf word, gebruik word." Die volwaardige Afrikaanse vaktaal wat vir interkollegiale gebruik juis op hierdie wyse oor ' $n$ halfeeu gegroei en ontwikkel het, staan nou voor die uitdaging om dit ook vir kommunale en transaksionele gebruik te doen.

'n Veeltalige (niemediese) woordeboek (Reynierse 1991) spreek tans gedeeltelik behoeftes op die gebied van kommunale en transaksionele kommunikasie aan, onder meer met geïllustreerde makroanatomiese terme. Visuele verduidelikings voorkom deels veroudering van verbale definisies, en is onmisbaar vir transaksionele kommunikasie met ongeletterdes. ${ }^{12}$ Bepaalde begrippe (allergie, bloeddruk e.d.) en sinsnedes wat tydens die kliniese interaksie gebruik word, word aangegee. 
Elektroniese telekommunikasietegnologie behoort op behoeftegedrewe wyse strategies benut te word, maar vervang nie 'n kernwoordeboek van presies gedefinieerde vakterme nie. Dit mag teikengebruikers skei op grond van rekenaargeletterdheid of -beskikbaarheid, en toegang tot internetkommunikasie en -interaksie. Dié wat toegang het tot elektroniese telekommunikasietegnologie, mag dalk woordeboeke minder nuttig vind. Die chronologiese verskyning van die SMD (1995) se uittrekselwoordeboeke dui waarskynlik aan hoe 100000 of meer trefwoorde en definisies kleiner teikengroepe selektief mag bereik. CD-ROM's en beknopte sakwoordeboeke gee gebruikers van vaktaalwoordeboeke toegang tot ' $n$ groter terminologiese bron. Spesifieke konsultante is nodig vir die ekstrahering van terme vir die aanverwante beroepe ("allied health professions") sodat 'n vaktaal-"Bybel" nie tydens paradigmaverskuiwings in 'n vaktaal-"Babel" ontaard nie.

Die PW gee waarskynlik sy eerste treë op 'n lang en avontuurlike pad.

\section{Aantekeninge}

1. SMD (199526: iv) het, benewens 'n internasionale edisie, ook vertaalde uitgawes in Grieks, Indies, Japannees, Portugees en Spaans.

2. In Suid-Afrika oorweeg die nuwe raad wat die Medisynebeheerraad vervang het, onder meer om voorsiening te maak vir jurisdiksie oor tradisionele en volksmedisynes. Dit mag mettertyd terminologiese implikasies hê. Die SAMNR se Navorsingsgroep vir Tradisionele Medisyne (Tramed) het pas (1998), in medewerking met tradisionele helers, 'n South African Traditional Healers' Primary Health Care Handbook gepubliseer.

3. Die eerste was dié van Thomas Blount (1656) Glossographia ... hard words together with Divinity Terms, Law, Physick, Mathematicks and other Arts and Sciences explicated, en Robert James (1743) Medical Dictionary, waaraan dr. Samuel Johnson, as "an amateur of physick" meegewerk het (MacNalty, 1965: v-vii). Met physick word hier "geneeskunde" bedoel.

4. Nederland word ná die Hervorming die toonaangewende akademies-mediese moondheid toe die Leidense mediese fakulteit 'n liberale toelatingsbeleid volg ten koste van die vroegste Italiaanse en Spaanse mediese fakulteite wat uitsluitlik Katolieke toegelaat het.

5. 'n Taakgroep van die Royal College of Physicians, Londen, is onlangs aangewys om die leemtes in dokter-pasiënt-kommunikasie te ondersoek, en het aanbevelings gemaak om dit reg te stel ("Improving Communication between Doctors and Patients: Summary and Recommendations of a Report of a Working Party of the Royal College of Physicians", Journal of the Royal College of Physicians (London) 31: 258-259, 1997).

6. In die 1950's was gelyktydig hersienings van anatomiese nomenklatuur aan die gang in Engeland (Birmingham Revision, BR), Switserland (Basle Nomina Anatomica, BNA) en Frankryk (Paris Nomina Anatomica, PNA). Eventueel maak akademiese inrigtings die keuse of hulle die Latynse (Nomina Anatomica hetsy van Basel hetsy van Parys) of die Engelse (BR) nomenklatuur wil gebruik, d.w.s. in die landstaal, óf Engels óf Anglo-Amerikaans. Natuurlik mag die landstaal óók Afrikaans of enige ander wetenskapstaal wees. Die NA term articulatio talonavicularis word in beide Engels en Anglo-Amerikaans talonavicular joint en in Afrikaans talonavikulêre gewrig. Die neiging van die Afrikaanse vakterminologie tot lati- 
nisering was destyds sterk, maar vandag word die internasionale tendens met die verafrikaansing van Latynse (NA) terminologie in die spreektaal gevolg.

7. Destyds senior lektor, Soölogie en Fisiese Antropologie, Universiteit van Stellenbosch

8. 'n Veertigtal teksboeke uit die laaste kwarteeu kon getel word, slegs twee waarvan vertalings was van Engelse teksboeke. Afrikaanse teksboeke in verloskunde geniet voorkeur bo hul Engelse eweknieë omdat die lae geboortesyfers in Europese lande outeurs minder ervare op hul vakgebied maak as hul Suid-Afrikaanse eweknieë. Plaaslik is die opleiding in verloskunde sodanig dat pasgekwalifiseerdes hul beperkings ken, maar enige gewone verlossing tuis kan doen, iets wat in Kanada byvoorbeeld tot bepaalde inrigtings beperk word.

9. 'n Naamsverandering van die tydskrif, voorheen die Suid-Afrikaanse Tydskrif vir Geneeskunde, en afgekort as SATvG, is in die 1980's gemaak ter wille van 'n tweetalige akroniem, SAMJ, op die buiteblad. Koste was 'n belangrike oorweging by die ontwerp en modernisering van die buiteblad. ' $n$ Meningsopname het getoon dat die hoofbeswaar teen joernaal was dat dit met die Engelse magazine verwar mag word. Ander wys daarop dat in Van Riebeeck se Joernaal, anders as in 'n tydskrif, slegs belangrike gebeurtenisse opgeteken is. Prof. H. W. Snyman se beswaar spesifiek was dat, soos HAT in 'n opmerking sê, joernaal in die betekenis van "wetenskaplike tydskrif" onder Engelse invloed is. Kosteoorwegings het uiteindelik die deurslag gegee!

10. In ligte, satiriese trant vra David Gunn ("An Appeal for Simpler Medical Terminology", Canadian Medical Association Journal 149: 1553-1667, 1993) o.a. waarom 'n trommelvlies juis 'n tympanum genoem moet word, waarom hoë (bloed)druk juis hipertensie moet wees, of musculus lattissimus dorsi meer sê as die grootste rugspier, en of patella enigiets anders as knieskyf kan beteken. Die Engelse argumente geld enige taal, óók Afrikaans, soos in bogenoemde (vertaalde) voorbeelde. Die kernbeswaar teen latinismes is: "It perpetuates the mystique that surrounds medicine: obscure medical terminology distances doctors from their patients" 'n moderne stelling van die probleem wat die 17de-eeuse handleidings tydens die mediese renaissance wou aanspreek!

11. In Manitoba, Kanada word tradisionele Chinese geneeskunde tans gewild (vlgs. ' $n$ brief van Edward J. Sheffmann "Traditional Chinese Medicine", Canadian Association Medical Journal 149: 1379, 1993). Daar het ook 'n veeltalige mediese woordeboek (Engels/Ojibwa/Cree/ Island dialect/ Deens) verskyn onder leiding van die Manitoba Association of Native Languages (MANL). Dié woordeboek sal, behalwe in klinieke, ook in skole gebruik word, maar die doel is nie soseer terminologies nie as om taalbewaring en trots op 'n nasionale erfenis te bevorder - in dié geval tradisionele of "aboriginal" geneeskunde (Rafuse 1993).

12. Daar is nog geen Afrikaanse mediese woordeboek met illustrasies of diagramme nie, maar dit word, dikwels ook in kleur, toenemend en op gespesialiseerde wyse gebruik in woordeboeke van Engelse mediese vaktaal. Stedman (1995) bevat illustrasies en diagramme met erkenning ontleen aan die elektroniese anatomie-atlas, A.D.A.M. Sommige diagramme en geanimeerde sketse in hierdie werk spreek 'n duisend woorde, en is van onskatbare waarde vir kommunikasie met ongeletterdes.

\section{Bronnelys}

\section{Woordeboeke}


Anderson, D.M. $1994^{28}$. Dorland's Illustrated Medical Dictionary. Philadelphia: W.B. Saunders.

Boshoff, S.P.E. 1953. Lys Ontleedkundige Terme Engels-Afrikaans-Latyn. Pretoria: Vaktaalburo, SuidAfrikaanse Akademie vir Wetenskap en Kuns.

Brink, A.J. 1979. Woordeboek van Afrikaanse Geneeskunde Terme. Kaapstad: Nasou.

Dirckx, John H. (Red.). 19973. Stedman's Concise Medical and Allied Health Dictionary. Baltimore: Williams \& Wilkins.

Hansen, Ralph. 1962. Beknopte Mediese Woordeboek / Concise Medical Dictionary. Kaapstad: Sarel Marais.

Labuschagne, F.J. en L.C. Eksteen. 19938. Verklarende Afrikaanse Woordeboek. Pretoria: J.L.van Schaik.

MacNalty, A.J. 1965³. Butterworths Medical Dictionary. Londen: Butterworths.

Mönnig, H.O., F.Z. van der Merwe en J.D. Louw. 1944. Voorlopige Geneeskundige Woordelys. Pretoria: Suid-Afrikaanse Akademie vir Wetenskap en Kuns.

Odendal, F.F. et al. 19973. Verklarende Handwoordeboek van die Afrikaanse Taal. Midrand: Perskor.

Reynierse, Cecile (Red.). 1991. South African Multi-Language Dictionary and Phrase Book. Cape Town: Reader's Digest Association S.A.

Rompel, H. 1975. Nurses' Dictionary English-Afrikaans / Verpleegsterswoordeboek Engels-Afrikaans. Kaapstad: Tafelberg.

Smith, Brian and Bentley E. Smith. 1986. Medical Teminology for the Health Professions. New York: Academic Press.

Snyman, H.W. 198833. Geneeskundige Woordeboek. Durban: Butterworth.

Spraycar, Marjory (Red.). 199526. Stedman's Medical Dictionary: Illustrated in Color. Baltimore: Williams \& Wilkins.

Taalkommissie. $1991^{8}$. Afrikaanse Woordelys en Spelreëls. Kaapstad: Tafelberg.

Van der Merwe, F.Z. en J.D. Louw. 1935. Mediese Woordeboek (met inbegrip van Veeartsenykundige, Tandheelkundige en Hospitaal-benaminge). Kaapstad: Nasionale Pers.

\section{Ander bronne}

Avery Jones, Francis (Red.). 1972. Richard Asher Talking Sense. Londen: Pitman Medical.

Blumberg, C. 1974. The Provision of Medical Literature and Information in the Cape. 1827-1973. Ongepubliseerde M.Bibl.-skripsie. Universiteit van Kaapstad.

Brummer, Tobie. 1986. Mediese joernalistiek onder die loep. Suid-Afrikaanse Mediese Joernaal 69: 275.

Burrows, E.H. 1958. A History of Medicine in South Africa. Kaapstad: A.A.Balkema.

Engel, G.L. 1977. The Need for A New Medical Model: A Challenge for Biomedicine. Science 196: 129-136.

Grobbelaar, C.S. 1954. Afrikaanse ontleedkundige terme: 'n resensie oor die lys uitgegee deur die Suid-Afrikaanse Akademie. Suid-Afrikaanse Tydskrif vir Geneeskunde 28: 480-483.

Häszner, J.F. 1793. Huislijk geneeskundig handboek voor de ingesetenen van Nederlands Afrika. Kaapse Argief, MOOC 14/143.

Heller, R. 1976. Priest-Doctors as a Rural Service. Medical History 20: 361-83.

Jordaan-Weiss, Milde. 1995. The National Terminology Services: A New Paradigm. Lexikos 5: 279285.

Magner, Lois N. 1992. A History of Medicine. New York: Marcel Dekker. 
Meyer, B.J. en Hester S. Meij. 1987. Fisiologie van die mens: 'n Algemene oorsig. Pretoria: HAUM.

Ncayiyana, Daniel J. 1998. Soweto se sjebeens en die toekoms van Afrikaans. Mini-redaksionele artikel. Suid-Afrikaanse Mediese Joernaal 88: 99.

Pretorius, J.C. 1992. Johann Friedrich Häszner (1764-1820). Suid-Afrikaanse Tydskrif vir Kultuurgeskiedenis 6: 124-134.

Rafuse, Jill. 1993. New Dictionary Provides Native-Language Equivalents of English Medical Terms. Canadian Medical Association Journal 149: 1537-1540.

Rosenberg, C.E. 1983. Medical Text and Social Context. Bulletin of the History of Medicine 57: $22-42$.

SAGTR. 1997. Registrasiegelde vir Beroepsrade, 1998. Omsendbrief.

Taylor, C.R. 1992. Great Expectations - The Reading Habits of Year II Medical Students. New England Journal of Medicine 326: 1436-9.

Wardwell, W.I. 1994. Alternative Medicine in the United States. Social Science and Medicine 38: 1061-1068.

World Health Organisation and UNICEF. 1978. Primary Health Care. Geneva: WHO.

Yankauer, A. 1997. The Recurring Popularity of Alternative Medicine. Perspectives in Biology and Medicine 41: 132-138.

\section{Afkortings gebruik in verwysings na woordeboeke}

AWS Afrikaanse Woordelys en Spelreëls (Taalkommissie. 19918)

DIM Dorland's Illustrated Medical Dictionary (Anderson, D.M. 1994)

GW Geneeskundige Woordeboek (Snyman, H.W. 19883)

HAT Verklarende Handwoordeboek van die Afrikaanse Taal (Odendal, F.F. et al. 19973)

SMD Stedman's Medical Dictionary: Illustrated in Color (Spraycar, Marjory. 199526)

SCD Stedman's Concise Medical and Allied Health Dictionary (Dirckx, John H. 1997)

VAW Verklarende Afrikaanse Woordeboek (Labuschagne, F.J. en L.C. Eksteen. 19938)

WAG Woordeboek van Afrikaanse Geneeskunde Terme (Brink, A.J. 1979) 